The impact of Foreign aid on Improving the Performance of Workers in ...

Dr/ Karim Abdel Megid Mohamed

\title{
The impact of Foreign aid on Improving the Performance of Workers in North African Countries - a comparative study
}

\section{Karim Abdel Megid Mohamed}

Lecturer in Arab academy for science technology and maritime transport Faculty of international transport and logistics

\begin{abstract}
:
This study empirically examines the role and impact of foreign aid (ODA) on the growth of performance of workers GDP for the period 2015-2018, using five developing countries in the North African region, namely, Egypt, Libya, Tunisia, Morocco and Algeria as a sample.
\end{abstract}

Key Words: foreign aid, performance of workers, economic growth, development aid, North African countries

\section{Introduction :}

During the past decade, the foreign aid's role in developing countries was a major topic for discussion among professionals of development area due to the international interest in Official Development Assistance (ODA), which is a necessary resource of funding for better development to achieve the United Nations Millennium Development Goals (Tang, 2017). 
The impact of Foreign aid on Improving the Performance of Workers in ...

Dr/ Karim Abdel Megid Mohamed

ODA has been used for many decades in developing countries, as a solution for various social and economic problems (Joshi, 2016), because it is considered an important source of financing development programs in these countries. The foreign aid can be defined as economic aid from one country to another aiming either to provide humanitarian relief during emergency situations to promote economic development, or to finance military expenditures (Hossain, 2014).

After the Second World War, ODA disbursements began and it is made up of physical hearing, skills, Knowledge, technology, grants and financial loans, which are regulated from donor countries to recipient countries (Anetor, 2020). ODA is considered a valuable channel through which the flow of capitals from the developed countries to the poorest countries is transferred (Saibu, 2017).

While the foreign aid remains the focus of literature on its aid, there is still much debate about its negative effects on economic growth and development, so that some authors have interpreted the positive relationship between this aid and the economic growth and performance of workers GDP growth, while some others have not been able to prove this (Udvari, 2018). 
The impact of Foreign aid on Improving the Performance of Workers in ...

Dr/ Karim Abdel Megid Mohamed

\section{The Research Problem}

The primary role of external development assistance, which provided in the form of loans and grants, is to alleviate poverty and promote the economic growth in developing countries which is reflected in the performance of workers GDP growth.

However, the official results of this aid did not achieve the basic goal at the global level in various countries. Over the past years, no less than trillion dollars of development aid have been transferred from rich countries to Africa, however in some African countries today the real income of a single person is less than what was in the United States of the seventies of the last century, as more than 350 million people live on less than one dollar per day (Phiri, 2017).

\section{Definition of Terms:}

\section{1- Official Development Assistance (ODA):}

The primary goal of many aid flows to developing countries is to promote economic development and welfare, which is usually measured by its impact on economic growth and poverty reduction (Konadu, 2016), and for the first time the term Official Development Assistance has been used by the Development Assistance Committee (DAC) and Organization for Economic Cooperation and Development (OECD). To measure foreign aid directed to developing countries, the term ODA was then used in 
The impact of Foreign aid on Improving the Performance of Workers in ...

Dr/ Karim Abdel Megid Mohamed

1999 by DAC, aiming to encourage the economic growth and welfare of the developing countries (Arsalan, 2019).

ODA is defined as designed government aid to promote economic development and welfare of developing countries by the Organization for Economic Cooperation and Development (OECD) (Tang, 2017).

\section{2- GDP performance of workers:}

This term is used as a tool to measure the living standards and economic prosperity for the country citizens and it is calculated by dividing the GDP of the country by the total population of this country (Arsalan, 2019).

\section{The Research Objective}

It is interesting to note that in recent years there has been a significant increase in aid flows to developing countries (Ekonayake, 2010), while the volume of international foreign aid changed according to the motives of the donor countries, and there was a bias in its distribution across countries, so the United Nations General Assembly adopted a proposal to allocate 3.7\% from the national income of the donor countries as Foreign Aid for developing countries (Masadh, 2020).

The aim of this paper is to study the effect of foreign aid on performance of workers GDP. This paper estimates five separate models by investigating five countries data in North African region during the period between 2015 and 2018.

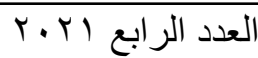

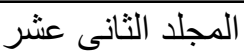


The impact of Foreign aid on Improving the Performance of Workers in ...

Dr/ Karim Abdel Megid Mohamed

\section{The Research Importance}

The foreign aid has become a major source for combating poverty and meeting the needs of citizens in developing countries during the past few decades (Durbarry, 2010), so that one of the criteria for the effectiveness for the its effectiveness is its contribution to improving economic growth, that is why a number of studies show that such contribution is a necessary condition for achieving sustainable development and poverty reduction (Jena, 2020).

However, the role and influence of international donors, including the World Bank, the United Nations and the International Monetary Fund, increased majority in the economic and social affairs of these countries (Hussain, 2018), and so the role of foreign aid has been confirmed with the specificity in the outline of the Millennium Development Goals (MDGs) initiatives, which emphasized meeting of 948 country's needs (Yiew, 2018), the importance of this study stems from the fact that it is one of the studies that focused on North African countries, where they were exposed to many difficult cases as a result of the Arab Spring revolutions and the overthrow of the ruling regimes, which affected the economic and social situation.

Furthermore, the results of this study can be used as a platform for gaining deep understanding of the effect of foreign aid on the 
The impact of Foreign aid on Improving the Performance of Workers in ...

Dr/ Karim Abdel Megid Mohamed

North African region economies and the growth of performance of workers GDP in this area.

\section{Literature Review:}

Several studies in the empirical literature discussing foreign aid, have attempted to assess whether aid is arriving to its goal which is promoting economic development and the welfare of developing countries (Moreira, 2005), and renewed interest recently in the causes and effects of foreign aid on the people income (Rena, 2013). The foreign aid and its role in economic development and prosperity still remain in the focus of the various literature, also still a great debate about the positive aspects and negative effects of that Aid on economic growth and development (Udvari et al., 2018).

Previous studies, which investigated the relationship between aid and economic growth, have yielded mixed results and have been criticized for their shortcomings, because the methodology related to the cross-country studies, as well as the country specific studies, failed to produce any conclusive results (Mallik, 2008). So that the role of Foreign Aid in the economic development processes of developing economies is a deep discussions topic as it has implications for poverty reduction (Arsalan, 2019).

In a study done by Alemu et al. (2015) entitled [Foreign Aid on economic growth in Africa: A comparison of low and middle- 
The impact of Foreign aid on Improving the Performance of Workers in ...

Dr/ Karim Abdel Megid Mohamed

income countries], 20 middle-income African countries and 19 low-income countries were studied over a 15 years period between 1995 and 2010, and they confirmed that in case of African low-income countries the foreign aid played a crucial role in stimulating the economic growth in these countries through supplementing resources protected financing such as savings, thus increasing the volume of investment and the capital stock in them.

In other research done by Tait et al. (2016) entitled [Foreign Aid and Economic Growth in Sub-Saharan Africa], aims to study the effect of foreign aid on this region during the period from 1970 to 2012, so samples from 25 African countries in SubSaharan Africa were studied and the results indicated that the Aid has significant positive impact on long-term growth in performance of workers GDP during this period of study.

In another study done by Galiani (2016) entitled [The effect of Aid on Growth: Evidence from a Quasi-Experiment], emphasized that the literature on aid and growth did not found a convincing variable to determine the causal effects of aid. A significant economic impact of development aid on growth has been found, especially in a single annual real growth in GDP which increased by about 0.35 points percentage.

Phiri (2017) did a research entitled [The Impact of Aid on the Economic Growth of Development Countries $\left(\mathrm{LDC}_{\mathrm{s}}\right)$ in Sub-Saharan Africa], which examined the impact growth of 12 countries with least 
The impact of Foreign aid on Improving the Performance of Workers in ...

Dr/ Karim Abdel Megid Mohamed

developed income in Sub-Saharan Africa over a period of 20 years, and the results indicate that the assistance has statistically negative impact on economic growth and growth promotion, possibly due to the misallocation of Aid or ineffective use of it.

Rahnama et al. (2017) did a research entitled [The effects of Foreign Aid on economic growth in developing countries], which highlighted the issue of the heterogeneous effects of foreign aid on growth in least developed countries, while previous studies have brought all developing countries together as homogeneous; although developing countries in fact differ greatly in developmental stages, and the results show that foreign aid has a beneficial effects in high-income countries at the later stage of development, so this indicates that countries need to acquire some help before foreign aid can help.

In the research done by Dreher et al. (2019), entitled [Does Foreign Aid really raise performance of workers income? A time series perspective] which analyzed the relationship between performance of workers income and foreign aid by using annual data of 5 year averages and examination of time series characteristics of the data, which confirmed that aid is generally appropriate little negative impact on performance of workers income especially in countries that depend heavily on aid.

Mahembe (2019) did research entitled [Foreign Aid, Poverty and Economic Growth in Developing Countries: A dynamic panel 
The impact of Foreign aid on Improving the Performance of Workers in ...

Dr/ Karim Abdel Megid Mohamed

data causality analysis], which examined the causal relationship between foreign aid, Poverty and Economic Growth in 82 developing countries during the period between 1981 and 2013. This study found a strong negative relationship between the poverty rate and the performance of workers gross domestic product of foreign aid.

In the study done by Abduvaliev et al. (2020) entitled [Patterns of Official Development Assistance in Tajikistan: Effects on Growth and Poverty Reduction], which aimed to assess the impact of official development assistance on economic growth and poverty reduction in Tajikistan, and it demonstrated that an increase of $1 \%$ in the official development assistance resulted in $1.6 \%$ increase in GDP performance of workers and $0.48 \%$ decrease in poverty levels in Tajikistan.

A.Lyew (2021) emphasized in his study entitled [Foreign Aid, Grassroots Activism, and the Strength of Applied Community Studies in Aid-Receiving Countries: The Case of Community Psychology], what affects the power of community psychology in countries who craves foreign aid? Where the development capacity is a major focus of donor countries and other international development agencies. The study explains the disparity in the strength of discipline over the impact of performance of workers GDP, income inequality, educational infrastructure, civil liberties and nonviolent activism. 
The impact of Foreign aid on Improving the Performance of Workers in ...

Dr/ Karim Abdel Megid Mohamed

\section{The Research Assumptions}

Is statistically significant impact of foreign aid on total growth of GDP performance of workers in North African countries?

\section{The following sub-hypotheses emerge from this hypothesis:}

Is statistically significant impact of foreign aid on the total growth of performance of workers GDP of the Arab Republic of Egypt?

Is statistically significant impact of foreign aid on the total growth of the performance of workers GDP of Algeria?

Is statistically significant impact of foreign aid on the total growth of performance of workers GDP of the Moroccan state?

Is statistically significant impact of foreign aid on the total growth of Tunisia's performance of workers GDP?

Is statistically significant impact of foreign aid on the total growth of the performance of workers GDP of the state of Libya?

\section{DATA AND METHODOLOGY}

The present study relies mainly on secondary sources of data. Data were collected from various articles published in books and magazines. The paper contains organized sections: the first section deals with the introduction and the second introduces the nature of the problem, the third section describes the main terms of the study, the fourth and fifth show the objectives of the study and its importance. The literature related to the study was 
The impact of Foreign aid on Improving the Performance of Workers in ...

Dr/ Karim Abdel Megid Mohamed

discussed in the sixth Section, The seventh section is devoted to research hypotheses, as for the data and the Methodology they are presented in the eighth section, while the other sections focused on the research variables, the research community and the study sample, then statistical analysis, hypothesis testing and finally the conclusion.

Data for the growth of performance of workers GDP was obtained from Databank World Development Indicators while ODA from World Development Indicators - World Bank Group. Data were obtained for the years of 2015 through 2019 (five years) for five developing countries. Empirical results from the literature provide indication that the impact of ODA be positive or negative toward the growth of performance of workers GDP.

The statistical analysis methods used in the research vary between descriptive statistical methods, which are arithmetic means and standard deviations, which were used in calculating the priorities of countries in the total performance of workers growth in the period (2015-2019), and the inferential statistical methods which are simple regression analysis and graded multiple regression analysis were used in Measuring hypothesis tests to find out the extent of influence between the variables, and a correlation matrix was used to measure the extent of the correlation between the variables and their dimensions. 
The impact of Foreign aid on Improving the Performance of Workers in ...

Dr/ Karim Abdel Megid Mohamed

Table No. (1) GDP performance of workers growth (\% annual)

\begin{tabular}{|c|c|c|c|c|c|}
\hline The year & $\mathbf{2 0 1 9}$ & $\mathbf{2 0 1 8}$ & $\mathbf{2 0 1 7}$ & $\mathbf{2 0 1 6}$ & $\mathbf{2 0 1 5}$ \\
Countryy & & & & & \\
\hline Egypt & 3.5 & 3.2 & 1.0 & 2.1 & 2.1 \\
\hline Algeria & -1.1 & -0.8 & $-0,8$ & 1.1 & 1.6 \\
\hline Morocco & 1.0 & 1.7 & 2.9 & -0.3 & 3.1 \\
\hline Tunisia & -0.1 & 1.5 & 0.8 & 0.0 & 0.1 \\
\hline Libya & 1.0 & 13.4 & 25.0 & -3.9 & -9.7 \\
\hline
\end{tabular}

Source: Databank World Development Indicators

Figure (1) GDP performance of workers growth

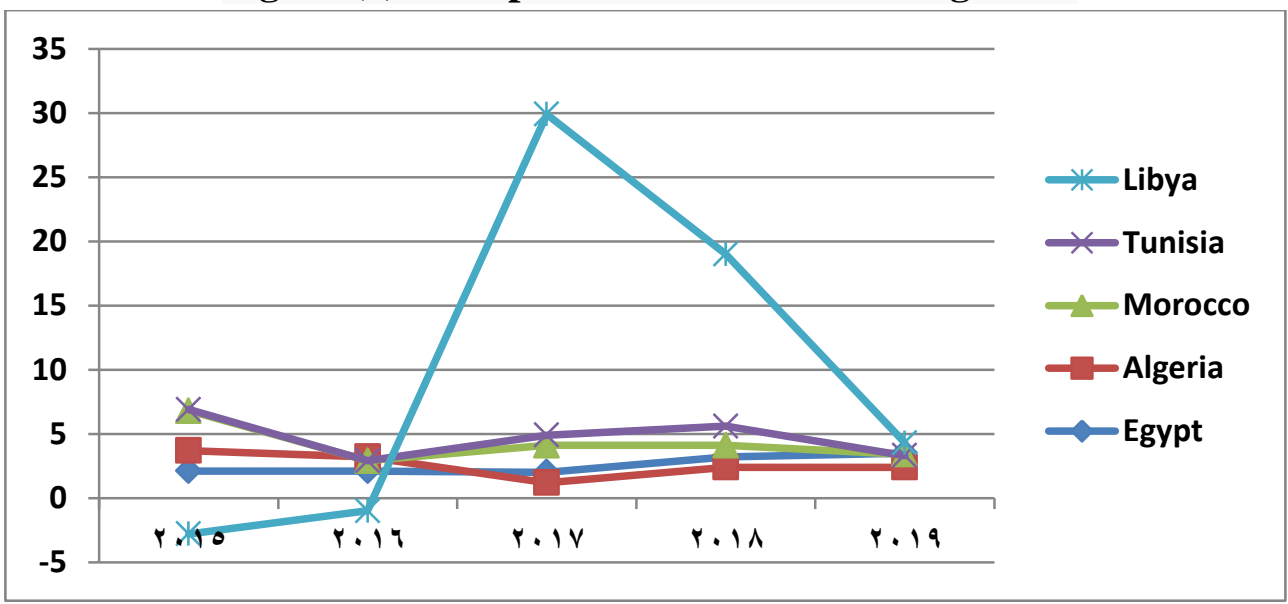

Source: Designed by the researcher 
The impact of Foreign aid on Improving the Performance of Workers in ...

Dr/ Karim Abdel Megid Mohamed

Net Official Development Assistance (ODA) consists of loan payments made on concessional terms (after deducting repayment of principal) and grants from official agencies and multilateral institutions. To promote economic development and prosperity in countries.

\begin{tabular}{|c|c|c|c|c|}
\hline $\begin{array}{c}\text { The year } \\
\text { Countryy }\end{array}$ & $\mathbf{2 0 1 5}$ & $\mathbf{2 0 1 6}$ & $\mathbf{2 0 1 7}$ & $\mathbf{2 0 1 8}$ \\
\hline Egypt & 2524530029 & 2437350098 & 32840000.15 & 2063739990 \\
\hline Algeria & 71129997.25 & 144550003.1 & 174679992.7 & 143979995.7 \\
\hline Morocco & 1518280029 & 2062310059 & 2416270020 & 811650024.4 \\
\hline Tunisia & 495869995.1 & 646820007.3 & 811640014.6 & 805270019.5 \\
\hline Libya & 157369995.1 & 179490005.5 & 431869995.1 & 303309997.6 \\
\hline
\end{tabular}

Table No. (2) Net ODA received (current US dollars)

Source: World Development Indicators - World Bank Group

Figure (2) Official Development Assistance

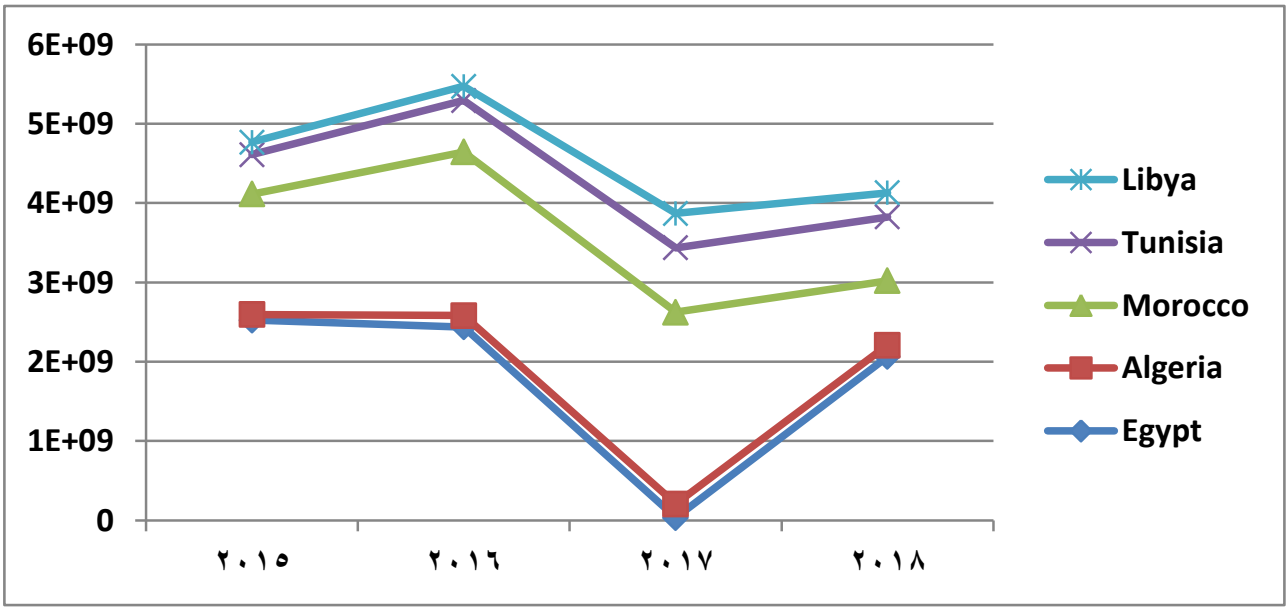

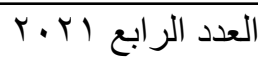


The impact of Foreign aid on Improving the Performance of Workers in ...

Dr/ Karim Abdel Megid Mohamed

Source: Designed by the researcher

Descriptive statistics of the study variables

Table No. (3)

Descriptive statistics of foreign aid to North African countries from (2015-2018)

\begin{tabular}{|c|c|c|c|c|c|}
\hline Variable & $\mathbf{N}$ & $\begin{array}{c}\text { Arithmetic } \\
\text { mean }\end{array}$ & $\begin{array}{c}\text { Standard } \\
\text { deviation }\end{array}$ & Minimum & Maximum \\
\hline Algeria & 4 & 1.3358 & 4.40368 & 7.11 & 1.75 \\
\hline Morocco & 4 & 1.7021 & 6.99162 & 8.12 & 2.42 \\
\hline Tunisia & 4 & 6.8990 & 1.50149 & 4.96 & 8.12 \\
\hline Egypt & 4 & 1.7646 & 1.17169 & 3.28 & 2.52 \\
\hline Libya & 4 & 2.6801 & 1.26719 & 1.57 & 4.32 \\
\hline
\end{tabular}


The impact of Foreign aid on Improving the Performance of Workers in ...

Dr/ Karim Abdel Megid Mohamed

Figure (3) an illustration of the foreign aid to North African countries from (2015-2018)

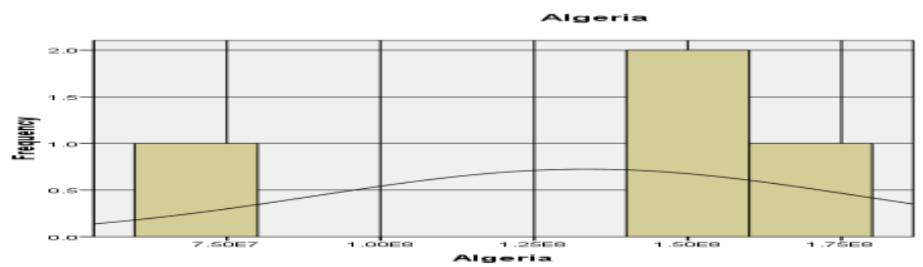

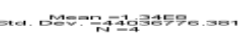

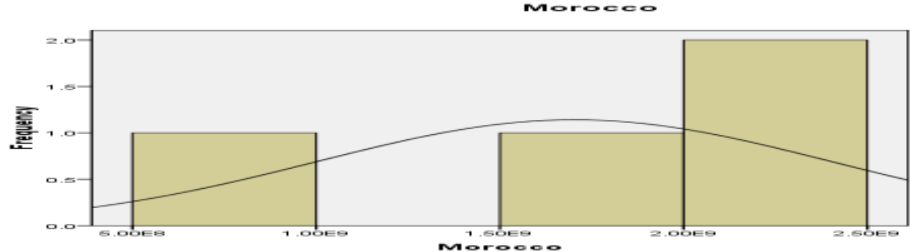

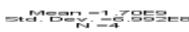

Trmisia

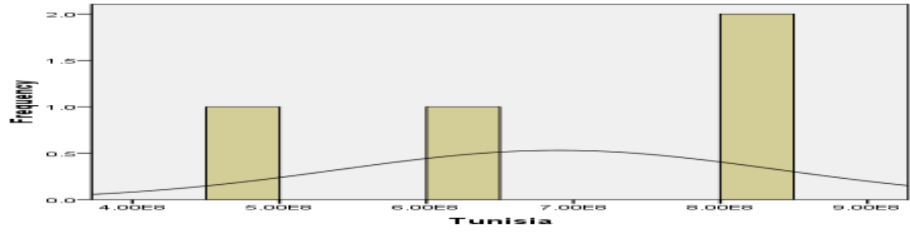

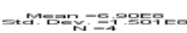

Easpe

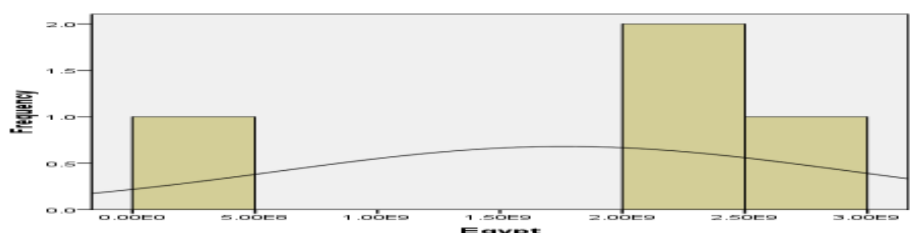

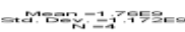

டioya

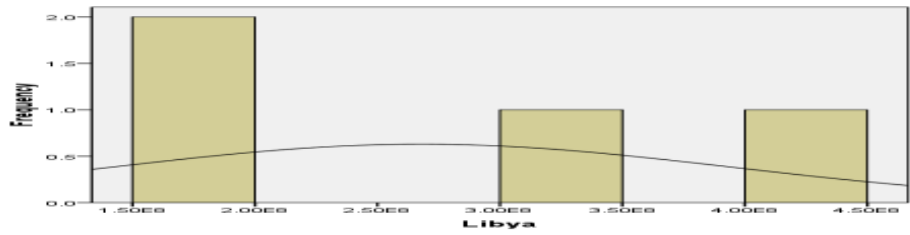


The impact of Foreign aid on Improving the Performance of Workers in ...

Dr/ Karim Abdel Megid Mohamed

Table No. (4)

Descriptive statistics: Total performance of workers growth in the period (2015-2019)

\begin{tabular}{|c|c|c|c|c|c|}
\hline Variable & $\mathbf{N}$ & $\begin{array}{c}\text { Arithmetic } \\
\text { mean }\end{array}$ & $\begin{array}{c}\text { Standard } \\
\text { deviation }\end{array}$ & Minimum & Maximum \\
\hline Egypt & 5 & 2.5800 & .71204 & 2.00 & 3.50 \\
\hline Algeria & 5 & 1.0800 & .32711 & .80 & 1.60 \\
\hline Morocco & 5 & 1.8000 & 1.20416 & .30 & 3.10 \\
\hline Tunisia & 5 & .5000 & .64420 & .00 & 1.50 \\
\hline Libya & 5 & 10.6000 & 9.39495 & 1.00 & 25.00 \\
\hline
\end{tabular}

Table No. (5)

Matrix of correlation between all research variables

\begin{tabular}{|c|c|c|c|c|c|r|r|r|r|r|r|}
\hline $\begin{array}{r}\text { Countr } \\
\mathbf{y}\end{array}$ & $\begin{array}{c}\text { Liby } \\
\mathbf{a}\end{array}$ & Tunisia & $\begin{array}{r}\text { Morocc } \\
\mathbf{0}\end{array}$ & Algeria & Egypt & F. Aid & Libya & Egypt & Tunisia & $\begin{array}{c}\text { Morocc } \\
\mathbf{0}\end{array}$ & Algeria \\
\hline Algeria & & & & & & & & & & & 1.000 \\
\hline $\begin{array}{c}\text { Morocc } \\
\mathbf{0}\end{array}$ & & & & & & & & & & 1.000 & .385 \\
\hline Tunisia & & & & & & & & & 1.000 & .014 & .900 \\
\hline Egypt & & & & & & & & 1.000 & -.668 & -.570 & -.699 \\
\hline Libya & & & & & & & 1.000 & -.936 & .864 & .279 & .779 \\
\hline F. Aid & & & & & & 1.000 & -.853 & .731 & -.662 & .120 & -.380 \\
\hline Egypt & & & & & 1.000 & -.331 & .104 & .251 & .448 & -.881 & .098 \\
\hline Algeria & & & & 1.000 & -.427 & .544 & -.802 & .610 & -.989 & -.049 & -.936 \\
\hline $\begin{array}{c}\text { Morocc } \\
\mathbf{0}\end{array}$ & & & 1.000 & .253 & -.191 & -.654 & .338 & -.431 & -.112 & .035 & -.314 \\
\hline Tunisia & & 1.000 & .141 & -.734 & .815 & -.786 & .652 & -.351 & .799 & -.535 & .458 \\
\hline Libya & 1.000 & .530 & .653 & -.533 & -.050 & -.912 & .931 & -.936 & .633 & .297 & .513 \\
\hline
\end{tabular}

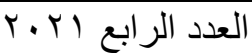


The impact of Foreign aid on Improving the Performance of Workers in ...

Dr/ Karim Abdel Megid Mohamed

\section{Test of hypotheses}

Is statistically significant impact of foreign aid on the total growth of GDP performance of workers in North African countries? The following sub-hypotheses emerge from this hypothesis:

\section{1- Is statistically significant impact of foreign aid on the} total growth of the performance of workers GDP of the State of Egypt?

Table No. (6) Coefficients ${ }^{\mathrm{a}}$

\begin{tabular}{|c|c|c|c|c|c|}
\hline \multirow[b]{2}{*}{ Hodel } & \multicolumn{2}{|c|}{ Unstandardized Coefficients } & \multirow{2}{*}{$\begin{array}{c}\begin{array}{c}\text { Standardized } \\
\text { Coefficients }\end{array} \\
\text { Beta }\end{array}$} & \multirow[b]{2}{*}{$\mathrm{t}$} & \multirow[b]{2}{*}{ Sig. } \\
\hline & $\mathrm{B}$ & Std. Error & & & \\
\hline Constant) & 3.548 & 2.437 & & 1.456 & .283 \\
\hline $\begin{array}{l}\text { performance } \\
\text { of workers }\end{array}$ & $-1.314 \mathrm{E}-9$ & .000 & $-.331-$ & $-.496-$ & .669 \\
\hline
\end{tabular}

t. Dependent Variable: Egypt

\section{The data of the previous table indicates the following:}

- There is no significant impact of foreign aid on the total growth of Egypt's performance of workers GDP.

- The correlation coefficient between foreign aid and performance of workers growth is $33.1 \%$. Based on this result, the first subhypothesis can be rejected and the alternative hypothesis accepted.

2- Is statistically significant impact of foreign aid on the total growth of performance of workers GDP of Algeria? 
The impact of Foreign aid on Improving the Performance of Workers in ...

Dr/ Karim Abdel Megid Mohamed

\begin{tabular}{|c|c|c|c|c|c|}
\hline \multirow[b]{3}{*}{ Model } & Table No. (7) & \multicolumn{4}{|c|}{ Coefficients $^{\mathrm{a}}$} \\
\hline & \multicolumn{2}{|c|}{ Unstandardized Coefficients } & \multirow{2}{*}{$\begin{array}{c}\begin{array}{c}\text { Standardized } \\
\text { Coefficients }\end{array} \\
\text { Beta }\end{array}$} & \multirow[b]{2}{*}{$\mathrm{t}$} & \multirow[b]{2}{*}{ Sig. } \\
\hline & B & Std. Error & & & \\
\hline (Constant) & $-.231-$ & 1.439 & & $-.161-$ & .887 \\
\hline $\begin{array}{l}\text { Performance of } \\
\text { vorkers }\end{array}$ & $1.433 \mathrm{E}-9$ & .000 & .544 & .916 & .456 \\
\hline
\end{tabular}

ı. Dependent Variable: Algeria

\section{The data of the previous table indicates the following:}

- There is no significant impact of foreign aid on the total growth of the performance of workers GDP of Algeria.

- The correlation coefficient between foreign aid and performance of workers growth was $54.4 \%$. Based on this result, the second subhypothesis can be rejected and the alternative assumption accepted.

\section{3- Is statistically significant impact of foreign aid on the} total growth of performance of workers GDP of the State of Morocco?

Table No. (8) Coefficients ${ }^{\mathrm{a}}$

\begin{tabular}{|c|c|c|c|c|c|}
\hline \multirow[b]{2}{*}{ Model } & \multicolumn{2}{|c|}{$\begin{array}{l}\text { Unstandardized } \\
\text { Coefficients }\end{array}$} & \multirow{2}{*}{\begin{tabular}{|c|}
$\begin{array}{l}\text { Standardized } \\
\text { Coefficients }\end{array}$ \\
Beta
\end{tabular}} & \multirow[b]{2}{*}{$\mathrm{t}$} & \multirow[b]{2}{*}{ Sig. } \\
\hline & B & Std. Error & & & \\
\hline Constant) & 7.374 & 4.436 & & 1.662 & .238 \\
\hline $\begin{array}{l}\text { Performance } \\
\text { of workers }\end{array}$ & $-5.895 \mathrm{E}-9$ & .000 & $-.654-$ & $-1.223-$ & .346 \\
\hline
\end{tabular}

ı. Dependent Variable: Morocco 
The impact of Foreign aid on Improving the Performance of Workers in ...

Dr/ Karim Abdel Megid Mohamed

Table No. (8) Coefficients ${ }^{\mathrm{a}}$

\begin{tabular}{|c|c|c|c|c|c|}
\hline \multirow[b]{2}{*}{ Model } & \multicolumn{2}{|c|}{$\begin{array}{l}\text { Unstandardized } \\
\text { Coefficients }\end{array}$} & \multirow{2}{*}{\begin{tabular}{|c|}
$\begin{array}{c}\text { Standardized } \\
\text { Coefficients }\end{array}$ \\
Beta
\end{tabular}} & \multirow[b]{2}{*}{$\mathrm{t}$} & \multirow[b]{2}{*}{ Sig. } \\
\hline & B & Std. Error & & & \\
\hline Constant) & 7.374 & 4.436 & & 1.662 & .238 \\
\hline $\begin{array}{l}\text { Performance } \\
\text { of workers }\end{array}$ & $-5.895 \mathrm{E}-9$ & .000 & $-.654-$ & $-1.223-$ & .346 \\
\hline
\end{tabular}

The data of the previous table indicates the following:

- There is no significant impact of foreign aid on the total growth of performance of workers GDP of the Moroccan state.

- The correlation coefficient between foreign aid and performance of workers growth is $65.4 \%$. Based on this result, the third sub-hypothesis can be rejected and the alternative assumption accepted.

\section{4- Is statistically significant impact of foreign aid on the total growth of Tunisia's GDP performance of workers?}

Table No. (9) Coefficients ${ }^{\mathrm{a}}$

\begin{tabular}{|c|c|c|c|c|c|}
\hline \multirow[b]{2}{*}{ Model } & \multicolumn{2}{|c|}{ Unstandardized Coefficients } & \multirow{2}{*}{$\begin{array}{c}\begin{array}{c}\text { Standardized } \\
\text { Coefficients }\end{array} \\
\text { Beta }\end{array}$} & \multirow[b]{2}{*}{$\mathrm{t}$} & \multirow[b]{2}{*}{ Sig. } \\
\hline & $\mathrm{B}$ & Std. Error & & & \\
\hline Constant) & 4.088 & 1.961 & & 2.085 & .172 \\
\hline $\begin{array}{l}\text { Performance of } \\
\text { vorkers }\end{array}$ & $-3.826 \mathrm{E}-9$ & .000 & $-.786-$ & $-1.795-$ & .214 \\
\hline
\end{tabular}

a. Dependent Variable: Tunisia 
The impact of Foreign aid on Improving the Performance of Workers in ...

Dr/ Karim Abdel Megid Mohamed

\section{The data of the previous table indicates the following:}

- There is no significant impact of foreign aid on the total growth of Tunisia's GDP performance of workers.

- The correlation coefficient between foreign aid and performance of workers growth was $78.6 \%$. Based on this result, the fourth subhypothesis can be rejected and the alternative assumption accepted.

\section{5- Is statistically significant impact of foreign aid on the total} growth of performance of workers GDP of the state of Libya?

Table No. (10) Coefficients ${ }^{\mathrm{a}}$

\begin{tabular}{|c|c|c|c|c|c|}
\hline \multirow[b]{2}{*}{ Model } & \multicolumn{2}{|c|}{ Unstandardized Coefficients } & \multirow{2}{*}{$\begin{array}{c}\text { Standardized } \\
\text { Coefficients } \\
\text { Beta }\end{array}$} & \multirow[b]{2}{*}{$\mathrm{t}$} & \multirow[b]{2}{*}{ Sig. } \\
\hline & $\mathrm{B}$ & Std. Error & & & \\
\hline Constant) & 64.716 & 16.551 & & 3.910 & .060 \\
\hline $\begin{array}{l}\text { Performance of } \\
\text { vorkers }\end{array}$ & $-5.673 \mathrm{E}-8$ & .000 & $-.912-$ & $-3.153-$ & .088 \\
\hline
\end{tabular}

1. Dependent Variable: Libya

The data of the previous table indicate the following:

- There is no significant impact of foreign aid on the total growth of Libya's performance of workers GDP.

- The correlation coefficient between foreign aid and performance of workers growth is $91.2 \%$. Based on this result, the first subhypothesis can be rejected and the null imposition can be accepted. 
The impact of Foreign aid on Improving the Performance of Workers in ...

Dr/ Karim Abdel Megid Mohamed

\section{6- Is statistically significant impact of foreign aid on the total growth of GDP performance of workers in North African countries?}

Table No. (11) Coefficients ${ }^{\mathrm{a}}$

\begin{tabular}{|c|c|c|c|c|c|}
\hline \multirow[b]{2}{*}{ Model } & \multicolumn{2}{|c|}{ Unstandardized Coefficients } & $\begin{array}{l}\text { Standardized } \\
\text { Coefficients }\end{array}$ & \multirow[b]{2}{*}{$\mathrm{t}$} & \multirow[b]{2}{*}{ Sig. } \\
\hline & B & Std. Error & Beta & & \\
\hline Constant) & 15.899 & 2.794 & & 5.690 & .030 \\
\hline $\begin{array}{l}\text { Total } \\
\text { Jrowth }\end{array}$ & $-1.327 \mathrm{E}-8$ & .000 & $-.951-$ & $-4.368-$ & .049 \\
\hline
\end{tabular}

ı. Dependent Variable: Performance of workers

\section{The data of the previous table indicate the following:}

- There is no significant impact of foreign aid on the total growth of the country's performance of workers GDP for the total of North African countries.

- The correlation coefficient between foreign aid and performance of workers growth is $95.1 \%$. Based on this result, the main assumption can be rejected and the alternative imposed.

\section{Conclusion}

This study makes an effort to determine whether there are relationships between foreign aid and economic growth represented by real performance of workers GDP, using countryspecific data.

The empirical result shows that in five countries In the North African region, the natural record of foreign aid as a percentage 
The impact of Foreign aid on Improving the Performance of Workers in ...

Dr/ Karim Abdel Megid Mohamed

of real GDP has a positive impact on the natural record of real GDP performance of workers.

However, this article does not investigate the underlying causes of the aid relationship and citizens' sense of prosperity. One can guess that a number of factors may underlie these results. For example, it could be due to a "bad policy" environment, as Burnside Dollar (2000) and Boone (1996) noted. Kosack and Tobin (2006) concluded that aid sometimes works against development in countries with very low levels of human capital, and that these countries have a very low human development index.

- It is clear that aid will work differently for some countries with a stable democratic political environment. It also appears likely that a large amount of aid to these countries meets humanitarian needs rather than expanding the productive capacity of the economy. From the declines in domestic saving, it appears that increased aid flows are an alternative to domestic saving rather than an addition to it. The reason may also be that the governments of some of these countries lack fiscal discipline and are using international resources to replace their efforts to increase domestic revenues and contain expenditures; the study showed that there is no relationship between foreign development aid and average performance of workers income from GDP. 
The impact of Foreign aid on Improving the Performance of Workers in ...

Dr/ Karim Abdel Megid Mohamed

- The study concludes that this aid does not improve the income of citizens within their societies (North African countries), and this is not due to the small volume of aid directed from donor countries, but it may be the reason that some of these countries did not benefit optimally, which will return to the income and welfare of citizens. In addition to the fragility of the economic conditions in these countries and their passage of economic, political and social crises during the period of the Arab Spring revolutions.

\section{Recommendations:}

- The poor classes should benefit from foreign aid.

- Work to improve the performance of employees by meeting all their requirements.

- Reducing dependence on loans and directing aid to capital formation.

- Diversification of foreign aid to promote growth in North African countries.

- Benefiting from foreign aid to know the obstacles working with the equipment and work to replace them.

- Paying attention to the performance of workers because it is the most important resource in the country.

- improving the infrastructure to prevent the spread of diseases, especially in the presence of Coved 90

- Those in charge of the country should be guided by real reform policies and real growth through realistic plans instead of relying on aid. 
The impact of Foreign aid on Improving the Performance of Workers in ...

Dr/ Karim Abdel Megid Mohamed

- Improving the performance of employees by creating the environment in which employees work.

- Security stability must be achieved and tourism revitalized due to the national income it achieves.

- Make annual reports to know the places that need to be developed and work to develop them through foreign aid.

- Achieving self-sufficiency, as it is not enough, the speed of growth is achieved. 
The impact of Foreign aid on Improving the Performance of Workers in ...

Dr/ Karim Abdel Megid Mohamed

\section{References :}

Dreher, Axel et. al., Does foreign aid really raise performance of workers income? A time series perspective, The Canadian Journal of Economics / Revue canadienne d'Economique , Vol. 45, No. 1 (February 2012), pp. 288-313.

Alemu ,Aye Mengistu et. al., Foreign aid on economic growth in Africa: A comparison of low and middle-income countries, South African Journal of Economic and Management Sciences (ISSN 1015-8812) , vol.18 n.4 Pretoria 2015.

Abduvaliev , Mubinzhon et. al., Patterns of Official Development Assistance in Tajikistan: effects on growth and poverty reduction, Revista Brasileira de Política Internacional (ISSN 0034-7329), vol.63 no.2, Aug 07, 2020.

A. Lyew, Dominique et. al., Foreign Aid, Grassroots Activism, and the Strength of Applied Community Studies in Aid-Receiving Countries: The Case of Community Psychology , Vanderbilt University, Nashville, USA, Vol. 30. Num. 1. January 2021. pp. 1 - 11.

Rahnama, Masha et. al., The effects of foreign aid on economic growth in developing countries, The Journal of Developing Areas, Tennessee State University College of Business, Volume 51, Number 3, 2017, pp. 153-171.

Tait, Lauren et. al., Foreign Aid and Economic Growth in Sub-Saharan Africa, University of Western Australia, Crawley, March 2016,pp.4-30.

Mahembe, Edmore et. al., Foreign aid, poverty and economic growth in developing countries: A dynamic panel data causality analysis, Cogent Economics \& Finance(ISSN: 2332-2039),2019,pp.2-17. 
The impact of Foreign aid on Improving the Performance of Workers in ...

Dr/ Karim Abdel Megid Mohamed

Phiri, Maurice W., The Impact of Aid on the Economic Growth of Developing Countries (LDCs) in Sub-Saharan Africa, Gettysburg Economic Review: Vol. 10, Article 4. , 2017, pp.28-42.

Joshi, Nikhil, "The Effect of Foreign Direct Investment, Foreign Aid and International Remittance on Economic Growth in South Asian Countries" (2016). Culminating Projects in Economics. p.7.

Galiani, Sebastian et. al., The Effect OF Aid on Growth: Evidence from a Quasi - experiment, National Bureau of Economic Research- 1050 Massachusetts Avenue -Cambridge, MA 02138, April 2016.

Tang, Kin-Boon et. al., Foreign Aid and Economic Growth in Developing Countries: Evidence from Sub-Saharan Africa, Theoretical Economics Letters (ISSN: 2162-2078), Scientific Research Publishing Inc., 2017, pp. 1474-1475.

Knack, Stephen, Aid Dependence and the Quality of Governance- A CrossCountry Empirical Analysis, Policy Research Working Paper-The World Bank, July 2000, pp.4.

Arsalan, Rahmatullah, Foreign Aid and Economic Development- A study of Foreign Aid and Its Effects and Relationship with Performance of workers Income of Afghanistan, Kabul, Afghanistan, April 2019, pp.8-1.

Udvari, Beáta et. al., Impacts of Aid for Innovation on Economic Growth in the Sub-Saharan African Countries, Mediterranean Journal of Social Sciences, Vol 9 No 4 , July 2018, pp.100.

Mallik ,Girijasankar, Foreign Aid and Economic Growth: A Cointegration Analysis of the Six Poorest African Countries, Economic Analysis \& Policy, Vol. 38 NO. 2, SEPTEMBER 2008, pp. rol-ror. 
The impact of Foreign aid on Improving the Performance of Workers in ...

Dr/ Karim Abdel Megid Mohamed

Yiew ,Thian-Hee et. al.., Does foreign aid contribute to or impeded economic growth?, Journal of International Studies, 2018, p. 22.

Hussain ,Aakif et. al., Foreign Aid and Economic Growth Nexus: A comparative study of Pakistan with four SAARC countries, Journal of the Research Society of Pakistan, Volume No. 5 5, Issue No. 1, 2018 , p. rr.

Hossain, Basharat, The Effect of Foreign Aid on the Economic Growth of Bangladesh, Journal of Economics and Development StudiesPublished by American Research Institute for Policy Development, ISSN: 2334-2382, Vol. 2, No. 2, June 2014 pp. १५-१६.

Jena ,Nihar Ranjan, Foreign aid and economic growth in sub-Saharan Africa, African Journal of Economic and Management Studies, Vol. 11 No. 1, 2020 ,pp. 147-168.

Rena, Ravinder, Is Foreign Aid Panacea for African Problems? The Case of Namibia, Managing Global Transitions, Volume11, 2013, pp. 223-231.

Durbarry, Ramesh et. al., New Evidence on the Impact of Foreign Aid on Economic Growth, Centre for Research in Economic Development and International Trade, University of Nottingham,2010, pp. 1-r.

Ekanayake ,E. M. et. al., The effect of foreign aid on economic growth in developing countries, Journal of International Business and Cultural Studies, 2010, pp. 2-r.

Chervin, Michal et. al., Economic Growth and the Volatility of Foreign Aid, Tinbergen Institute ,Amsterdam (The institute for economic research of the Erasmus Universiteit Rotterdam), 2010, pp. 3-5. 
The impact of Foreign aid on Improving the Performance of Workers in ...

Dr/ Karim Abdel Megid Mohamed

Masadh , Mostafa Abdelaziz et. al.,The Impact of Foreign Aid Structure on Economic Growth in Jordan "1975-2014”, Jordan Journal of Economic Sciences, 7 Volume 1 Issue, 2020, pp. I-r.

Konadu ,Paul Appiah, The Effect of Foreign Aid on Economic Growth in Ghana, African Journal of Economic Review, Volume IV, Issue 2, July 2016, pp. 249-251.

Moreira, Sandrina Berthault , Evaluating The Impact of Foreign aid on Economic Growth: a Cross-Country Study, Journal of Economic Development, Volume 30, Number 2, December 2005, pp. 26-28.

Anetor, Friday Osemenshan et. al.,The impact of foreign direct investment, foreign aid and trade on poverty reduction: Evidence from Sub-Saharan African countries, Cogent Economics \& Finance,2020, pp. ¿_o.

Saibu, Olufemi, Foreign aid, fiscal optimality and economic growth in Nigeria, SPOUDAI - Journal of Economics and Business, ISSN 2241424X, University of Piraeus, Piraeus, Vol. 67, Iss. 4, 2017,pp. 85-99.

Udvari , Beáta et. al., Impacts of Aid for Innovation on Economic Growth in the Sub-Saharan African Countries, Mediterranean Journal of Social Sciences, Vol 9 No 4, July 2018, pp. 85-99. 